\title{
Assessment of Conventional Solvent Extraction vs. Supercritical Fluid Extraction of Khella (Ammi visnaga L.) Furanochromones and Their Cytotoxicity
}

\author{
Noha Khalil ${ }^{1, *(\mathbb{D}, \text { Mokhtar Bishr }}{ }^{2}$, Mohamed El-Degwy ${ }^{2}$, Mohamed Abdelhady ${ }^{2}$, Mohamed Amin $^{2}$ \\ and Osama Salama ${ }^{1}$ \\ 1 Department of Pharmacognosy and Medicinal Plants, Faculty of Pharmaceutical Sciences and Pharmaceutical \\ Industries, Future University in Egypt, Cairo 11835, Egypt; osalama@fue.edu.eg \\ 2 Arab Company for Pharmaceuticals and Medicinal Plants, (Mepaco-Medifood), AlSharqiya 11361, Egypt; \\ mbishr_2000@yahoo.com (M.B.); Degwys78@hotmail.com (M.E.-D.); magdi_science@hotmail.com (M.A.); \\ alichem2005@yahoo.com (M.A.) \\ * Correspondence: noha.hassan@fue.edu.eg; Tel.: +20-10-0356-6515
}

Citation: Khalil, N.; Bishr, M.; El-Degwy, M.; Abdelhady, M.; Amin, M.; Salama, O. Assessment of Conventional Solvent Extraction vs. Supercritical Fluid Extraction of Khella (Ammi visnaga L.) Furanochromones and Their Cytotoxicity. Molecules 2021, 26, 1290 https://doi.org/10.3390/ molecules 26051290

Academic Editors: Ana Paula Duarte, Ângelo Luís and Eugenia Gallardo

Received: 5 February 2021

Accepted: 24 February 2021

Published: 27 February 2021

Publisher's Note: MDPI stays neutra with regard to jurisdictional claims in published maps and institutional affiliations.

Copyright: (C) 2021 by the authors Licensee MDPI, Basel, Switzerland. This article is an open access article distributed under the terms and conditions of the Creative Commons Attribution (CC BY) license (https:// creativecommons.org/licenses/by/ $4.0 /)$.

\begin{abstract}
Background: Khella (Ammi visnaga Lam.) fruits (Apiaceae) are rich in furanochromones, mainly khellin and visnagin, and are thus incorporated in several pharmaceutical products used mainly for treatment of renal stones. Methods: The objective of this study was to compare the yield of khellin and visnagin obtained using different conventional solvents and supercritical fluid extraction (SCFE) with carbon dioxide (containing 5\% methanol as co-solvent). Water, acetone and ethanol (30\% and 95\%) were selected as conventional solvents. Results: Highest extract yield was obtained from $30 \%$ ethanol $(15.44 \%)$, while SCFE gave the lowest yield (4.50\%). However, the percentage of furanochromones were highest in SCFE (30.1\%), and lowest in boiling water extract (5.95\%). HPLC analysis of conventional solvent extracts showed other coumarins that did not appear in supercritical fluid extraction chromatogram due to non-selectivity of solvent extraction. Ammi visnaga extracts as well as standard khellin and visnagin were tested for their cytotoxic activity using sulforhodamine B assay on breast cancer (MCF-7) and hepatocellular carcinoma (Hep G2) cell lines. Results revealed a strong cytotoxic activity ( $\mathrm{IC}_{50}<20 \mu \mathrm{g} / \mathrm{mL}$ ) for the SCFE and standard compounds (khellin and visnagin) ( $\mathrm{IC}_{50}$ ranging between $12.54 \pm 0.57$ and $17.53 \pm 1.03 \mu \mathrm{g} / \mathrm{mL}$ ). However, ethanol and acetone extracts had moderate cytotoxic activity $\left(\mathrm{IC}_{50} 20-90 \mu \mathrm{g} / \mathrm{mL}\right)$ and aqueous extract had a weak activity $\left(\mathrm{IC}_{50}>90 \mu \mathrm{g} / \mathrm{mL}\right)$. Conclusions: Thus, supercritical fluid extraction is an efficient, relatively safe, and cheap technique that yielded a more selective purified extract with better cytotoxic activity.
\end{abstract}

Keywords: Ammi visnaga; khellin; supercritical fluid extraction; visnagin; MCF-7

\section{Introduction}

Ammi visnaga L. (Apiaceae) is a popular commercial medicinal plant indigenous to Egypt and widely cultivated in the Mediterranean region and Europe [1]. The plant is industrially important as it is employed worldwide in many pharmaceutical products; either its extract or isolated active constituents [2]. It is widely used for its antispasmodic properties [3]. It relieves kidney stones, used in some heart diseases like angina, as well as hypertriglyceridemia [4-9]. These medicinal effects are attributed to its coumarin content [10]. Two types of coumarins had been identified in A. visnaga: furanochromones (mainly khellin and visnagin) and pyranocoumarins (mainly samidin, visnadin and dihydrovisnadin) [11-13]. Recent studies also reported that khellin and visnagin, as well as their derivatives, are candidate drugs for treatment of several types of tumors, inflammatory diseases and epilepsy $[14,15]$. The amount of these compounds varies widely according to genetic as well as environmental factors $[7,16]$. Moreover, different extraction methods affect their yield. Individual compounds present in A. visnaga have different pharmacological activities. Khellin, for example is used to prevent renal crystal deposition $[4,17]$, 
while visnagin is a strong vasorelaxant [18]. Therefore, there is a need for the individual separation of these compounds from other coumarins present in the plant. Several green techniques have been recently implicated for natural product extraction to achieve industrial sustainability. These include, for example, molecular imprinting technology, solvent-resistant nanofiltration, deep eutectic solvent-based microwave-assisted extraction and supercritical fluid extraction [19-22]. Supercritical fluid extraction (SCFE), especially with carbon dioxide, has been recently applied in different fields; including natural products, metal cation extraction, polymer synthesis and particle nucleation [23-25]. It has been applied in the extraction of several essential oils such as orange, lemon, hawthorn, chamomile, oregano and rose oils [26]. It has also been used for the extraction of carotenoids from Spirulina platensis strain Pacifica microalgae spirulina [27], tropane alkaloids from Datura candida [28], lycopene from tomatoes [29], azadirachtin from neem seed kernels [30], oleoresins from Calendula officinalis [31] and chromones from Saposhnikoviae radix [32]. Several studies have demonstrated that SCFE may be superior to different conventional extraction methods, with regards to cleanliness, selectivity, time and cost saving, as well as possibility of manipulating the composition of the extracts according to the desired use [33].

The present study aimed at comparing the yield of furanochromones (khellin and visnagin) from $A$. visnaga fruits using different solvents as well as SCFE technique, in addition to assessing the in-vitro cytotoxic activity of the obtained extracts. This is to provide an industrially applicable extraction method that is fast, selective, relatively safe and cost effective, as well as to evaluate the effect of extraction technique on the cytotoxic activity.

\section{Results}

\subsection{Conventional Solvent Extraction vs. Supercritical Fluid Extraction of Furanochromones}

Dry extract yield, total content of furanochromones, as well as their percentage yield in each prepared extract is shown in Table 1. Although A. visnaga aqueous extract was easily converted to dry powder, however, it gave the least yield of furanochromones $(82.11 \pm 2.1 \mathrm{~g}, 5.95 \% \mathrm{w} / \mathrm{w})$. Ethanol $95 \%$ gave the highest yield of furanochromones amongst the tested conventional solvents $(111.1 \pm 2.4 \mathrm{~g}, 8.23 \% w / w)$. Although the 30\% ethanol extract gave a relatively lower furanochromones yield $(101.74 \pm 1.9 \mathrm{~g}, 6.59 \% \mathrm{w} / \mathrm{w})$, than that of ethanol $95 \%$, its physical properties were much better, while also it is the most industrially economic and low-cost solvent used commercially worldwide. Supercritical fluid extraction of furanochromones from $A$. visnaga fruits yielded a white, slightly fatty extract with strong characteristic odor. This extract had the best yield of furanochromones $(135.0 \pm 52.34 \mathrm{~g}, 30.1 \% \mathrm{w} / \mathrm{w})$.

Table 1. Average yields and furanochromones content in A. visnaga tested extracts.

\begin{tabular}{|c|c|c|c|c|c|c|c|c|}
\hline \multirow{2}{*}{ Solvent Used } & \multirow{2}{*}{$\begin{array}{c}\text { Solvent } \\
\text { Temperature } \\
\left({ }^{\circ} \mathrm{C}\right)\end{array}$} & \multirow{2}{*}{$\begin{array}{c}\text { Physical Properties } \\
\text { Of The Obtained } \\
\text { Extract }\end{array}$} & \multirow{2}{*}{$\begin{array}{l}\text { Total Solid } \\
\text { Extract Yield } \\
\text { (G) }\end{array}$} & \multirow{2}{*}{$\begin{array}{c}\text { Total Solid } \\
\text { Extract Yield } \\
(\%)\end{array}$} & \multicolumn{4}{|c|}{ HPLC Analysis } \\
\hline & & & & & Kh. (\%) & Vis. (\%) & Kh. + Vis. (g) & Kh. + Vis.\% \\
\hline Boiling water & 100 & Soft brown sticky & $1380.7 \pm 30.22$ & $13.807 \pm 0.32$ & $5.03 \pm 0.06$ & $0.92 \pm 0.08$ & $82.11 \pm 2.33$ & $5.95 \pm 0.14$ \\
\hline 95\% Ethanol & $45-50$ & Soft light brown & $1350.6 \pm 25.67$ & $13.506 \pm 0.25$ & $6.03 \pm 0.07$ & $2.20 \pm 0.02$ & $111.1 \pm 3.58$ & $8.23 \pm 0.09$ \\
\hline $30 \%$ Ethanol & $45-50$ & Soft dark brown & $1544.1 \pm 51.25$ & $15.441 \pm 0.51$ & $5.03 \pm 0.03$ & $1.56 \pm 0.02$ & $101.74 \pm 2.01$ & $6.59 \pm 0.05$ \\
\hline Acetone & $45-50$ & Soft fatty greenish & $507.5 \pm 11.69$ & $5.075 \pm 0.11$ & $13.71 \pm 0.12$ & $4.78 \pm 0.09$ & $93.74 \pm 3.45$ & $18.49 \pm 0.21$ \\
\hline SCFE & 45 & $\begin{array}{l}\text { Yellowish white, } \\
\text { slightly fatty, strong } \\
\text { characteristic odor }\end{array}$ & $450.8 \pm 8.58$ & $4.508 \pm 0.81$ & $28.8 \pm 1.22$ & $2.01 \pm 0.04$ & $135 \pm 3.22$ & $30.1 \pm 1.56$ \\
\hline
\end{tabular}

\subsection{HPLC Analysis of Conventional Solvents and SCF Extracts}

HPLC fingerprint chromatogram of the SCF and conventional solvents extracts are shown in Figure 1. Khellin and visnagin retention times were $9.3 \mathrm{~min}$. and $11.1 \mathrm{~min}$., respectively. However, the HPLC chromatogram of conventional solvents extracts showed other minor furanochromones which did not appear in case of supercritical fluid extraction. 


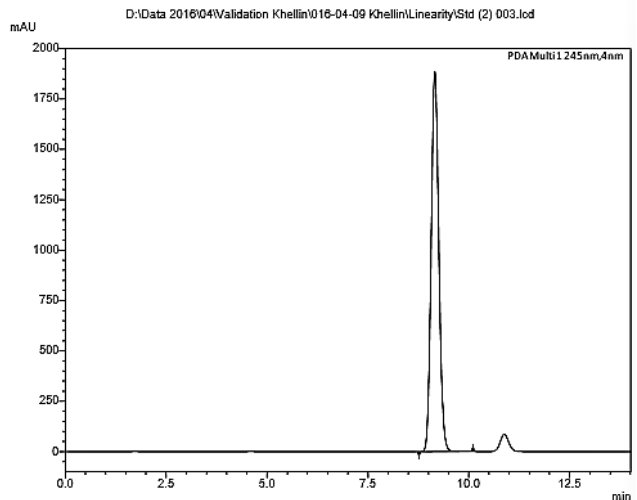

(a)



(c)

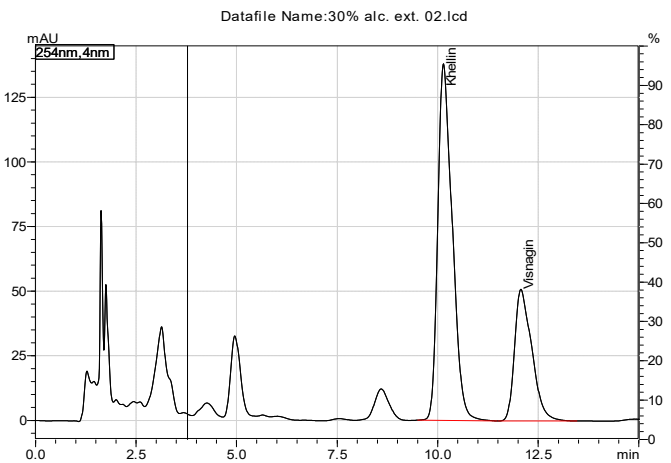

(e)

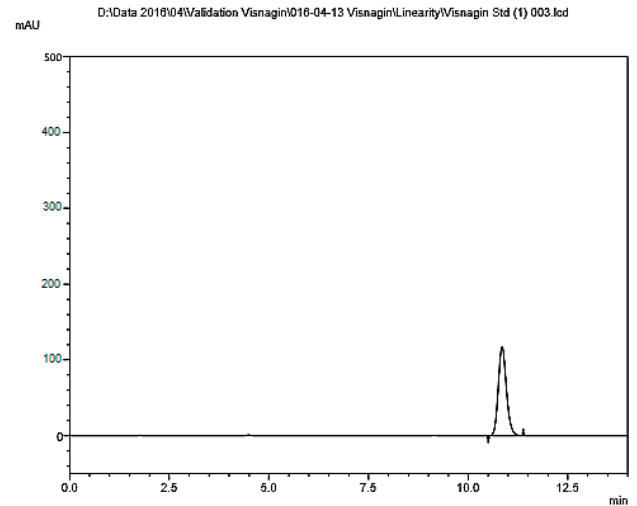

(b)

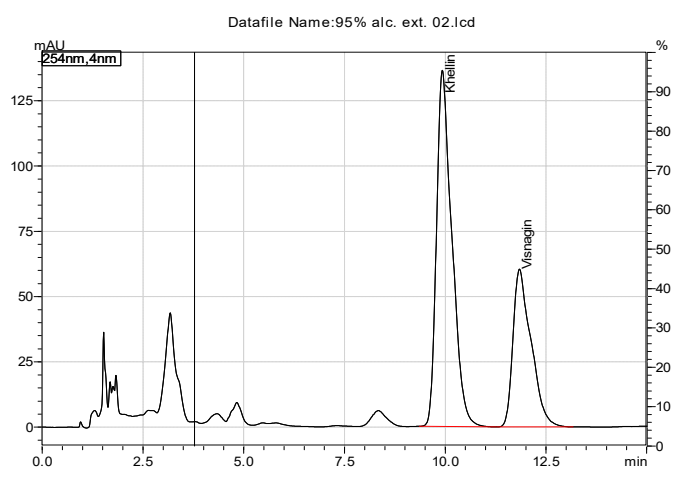

(d)

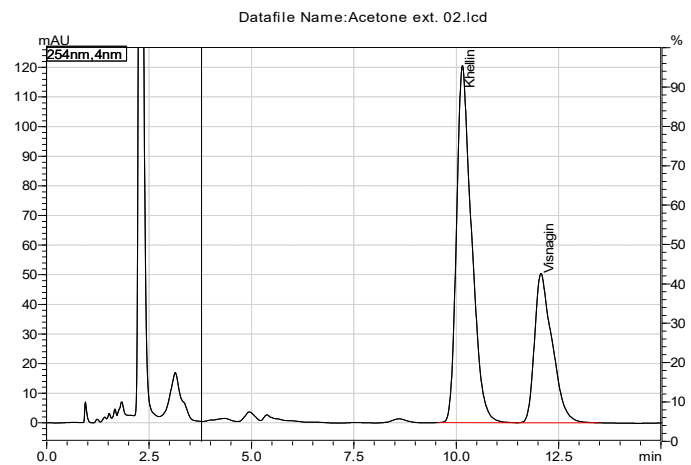

(f)

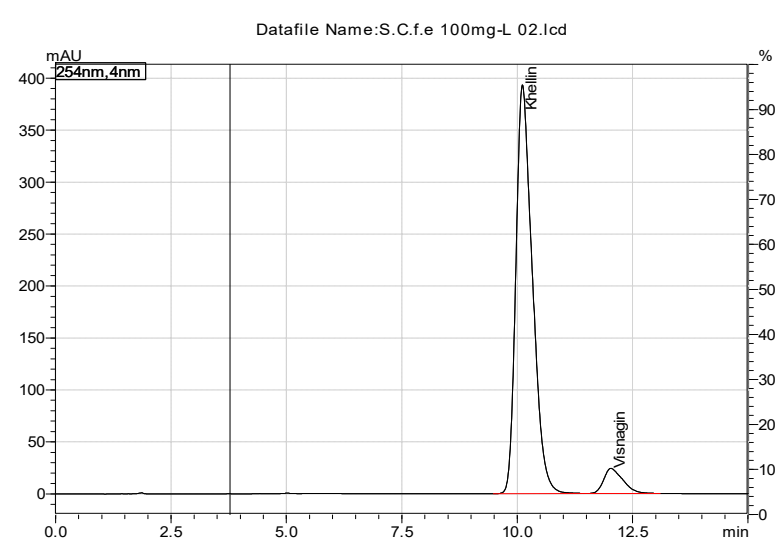

(g)

Figure 1. HPLC chromatograms of standard compounds and all tested extracts. (a) standard khellin, (b) standard visnagin, (c) aqueous extract, (d) 95\% ethanolic extract, (e) 30\% ethanolic extract, (f) acetone extract, (g) supercritical fluid extract. 


\subsection{In-Vitro Cytotoxic Activity of A. visnaga Extracts, Standard Khellin and Visnagin}

Ammi visnaga extracts, as well as standard khellin and visnagin, were tested for their cytotoxic activity using SRB assay. Results revealed a strong cytotoxic activity for the SCFE and standard compounds (khellin and visnagin) ( $\mathrm{IC}_{50}$ ranging between $12.54 \pm 0.57$ and $17.53 \pm 1.03 \mu \mathrm{g} / \mathrm{mL}$ ); however, the ethanol and acetone extracts had moderate cytotoxic activity and aqueous extract had a weak activity (Table 2).

Table 2. In-vitro cytotoxic activity of A. visnaga extracts, standard khellin, visnagin and doxorubicin.

\begin{tabular}{ccccc}
\hline Test & Hep G2 & SI & MCF-7 & SI \\
\hline & $\mathrm{IC}_{50}(\mu \mathrm{g} / \mathrm{mL})$ & & $\mathrm{IC}_{50}(\mu \mathrm{g} / \mathrm{mL})$ & \\
\hline Boiling water extract & $112.58 \pm 5.69^{\mathrm{aB}}$ & 2.11 & $123.87 \pm 6.22^{\mathrm{aB}}$ & 2.69 \\
\hline $30 \%$ Ethanol extract & $51.22 \pm 3.12^{\mathrm{aB}}$ & 2.89 & $33.96 \pm 2.45^{\mathrm{aB}}$ & 3.11 \\
\hline $95 \%$ Ethanol extract & $45.28 \pm 2.33^{\mathrm{aB}}$ & 2.14 & $59.15 \pm 4.25^{\mathrm{aB}}$ & 2.55 \\
\hline Acetone extract & $89.12 \pm 4.23^{\mathrm{aB}}$ & 1.23 & $88.14 \pm 3.45^{\mathrm{aB}}$ & 1.55 \\
\hline SCFE & $17.53 \pm 1.03^{\mathrm{bB}}$ & 3.15 & $15.39 \pm 0.58^{\mathrm{bB}}$ & 4.57 \\
\hline Khellin & $13.86 \pm 0.88^{\mathrm{bB}}$ & 3.96 & $12.54 \pm 0.57^{\mathrm{bB}}$ & 3.24 \\
\hline Visnagin & $15.98 \pm 0.66^{\mathrm{bB}}$ & 3.78 & $13.79 \pm 0.43^{\mathrm{bB}}$ & 2.78 \\
\hline Doxorubicin & $4.93 \pm 0.26^{\mathrm{A}}$ & & $3.58 \pm 0.31^{\mathrm{A}}$ &
\end{tabular}

Values are \pm SEM $(n=3)$, means followed by different letters in same column denote significant difference at $p<0.05$, paired-t-test. Lowercase letters compare means of test samples, uppercase letters compare means of sample with the standard doxorubicin. SI: Selectivity index was calculated as the ratio of the $\mathrm{IC}_{50}$ values on V79 cells to those in the tested cancer cell lines. SI $>3$ indicates a promising activity.

\section{Discussion}

Ammi visnaga L. is an important medicinally active plant which is incorporated in several pharmaceutical preparations used worldwide [2]. The main pharmacologically active compounds in this plant are the furanochromones; khellin and visnagin. Therefore, a convenient large-scale production technique is needed for those compounds. This study aimed at comparing the yield of furanochromones from $A$. visnaga fruits using different solvents, as well as SCFE technique, in addition to assessing the in-vitro cytotoxic activity of the prepared extracts. Boiling water, 30\% ethanol, $95 \%$ ethanol and acetone were used as conventional solvents for extraction of furanochromones from A. visnaga fruits. Although water is available, safer, and cheaper than other solvents used, it showed many drawbacks such as need for long durations and much energy for its removal; also, furanochromones yield $(82.11 \pm 2.1 \mathrm{~g}, 5.95 \% \mathrm{w} / \mathrm{w})$ was lower than yields obtained in other methods. However, its extract was easily converted to dry extract. Ethanol $95 \%$ extract gave the highest yield of furanochromones $(111.1 \pm 2.4 \mathrm{~g}, 8.23 \% \mathrm{w} / \mathrm{w})$, but its high cost is a major industrial drawback. Through different trials to replace the expensive ethanol by water and to reduce its hazards and cost, it was found that 30\% ethanol gave the best extract and relatively lowered the cost with quite good yield and quality $(101.74 \pm 1.9 \mathrm{~g}, 6.59 \% \mathrm{w} / \mathrm{w})$. Supercritical fluid extraction of furanochromones from A. visnaga fruits yielded a white, slightly fatty extract with strong characteristic odor. This extract had the best yield (135.0 $\pm 3.22 \mathrm{gm}$, $30.1 \% w / w)$ and best physical properties. HPLC chromatogram of all conventional extracts showed other minor compounds which did not appear in case of supercritical fluid extract due to the non-selectivity of the solvent extraction, which also impacted the color of the extract from white color to brown color due to relative extraction of other coloring matters and pigments in the fruits as shown in Figure 1.

The supercritical extraction method is a new separation technique that has been developed in recent years. Both temperature and pressure of the supercritical fluid are higher than the critical point, and thus the supercritical fluid has similar density to an ordinary fluid and many substances have a good solubility in it. Meanwhile, it also keeps the transfer properties and easy penetration characteristics of gas. Several studies have proved that SCF is advantageous over conventional solvent extraction. This may be due to 
the properties of supercritical fluids, which have different diffusivity, dielectric constant, density and viscosity. The high diffusivity, together with low viscosity of SCF, improve their diffusion through the plant material during the extraction process, especially under reduced pressure [34]. Altering the extraction conditions, such as extractor volume [34], temperature, pressure, and flow rate of both $\mathrm{CO}_{2}$ and the used co-solvent may also favor the extraction of certain compounds in the extract, which gives the SCFE technique a selectivity advantage over conventional extraction methods [35].

Moreover, SCFE has been reported to be superior to several conventional extraction methods, with regards to cleanliness, being environmental friendly, selectivity, time and cost saving in the long run, as well as possibility of manipulating the composition of the extracts according to the desired use [33].

Ammi visnaga extracts, as well as standard khellin and visnagin, were tested for their cytotoxic activity using SRB assay. Results revealed a strong cytotoxic activity $\left(\mathrm{IC}_{50}<20 \mu \mathrm{g} / \mathrm{mL}\right.$ ) for the SCFE and standard compounds (khellin and visnagin) (IC 50 ranging between $12.54 \pm 0.57$ and $17.53 \pm 1.03 \mu \mathrm{g} / \mathrm{mL}$ ). However, ethanol and acetone extracts had moderate cytotoxic activity $\left(\mathrm{IC}_{50} 20-90 \mu \mathrm{g} / \mathrm{mL}\right.$ ) and aqueous extract had a weak activity $\left(\mathrm{IC}_{50}>90 \mu \mathrm{g} / \mathrm{mL}\right)$ [36]. Cytotoxic activity of $A$. visnaga extracts has been reported in several studies. Khellin and visnagin were also previously reported to have cytotoxic effects against several cell lines including MCF-7 and Hep G2 [37-39]. The high purity of furanochromones in SCFE may account for its better cytotoxic activity.

\section{Materials and Methods}

\subsection{Plant Material}

Fruits of A. visnaga were purchased from the Ministry of Agriculture \& Land Reclamation, Giza, Egypt \& planted in Mepaco medicinal farm. Plant identity was verified by Dr. Mohamed EL Gebaly, Department of Botany, National Research Centre in Egypt. Voucher specimens are deposited in the Pharmacognosy research lab at the Future University in Egypt and labeled 112-AV. Authentic khellin and visnagin were obtained from Sigma Aldrich (Darmstadt, Germany).

\subsection{Preparation of the Plant Extracts}

\subsubsection{Conventional Solvent Extraction}

Maceration technique was applied for solvent extraction of total furanochromones from $A$. visnaga fruits using three different solvents. Different trials were used on a large scale using a solvent extraction system. Only solvents with minimum hazard were used; basically ethanol 95\%, 30\% ethanol, acetone and boiling purified water. Ten $\mathrm{kg}$ of A. visnaga fruits (previously crushed and sieved on sieve $1 \mathrm{~mm}$ ) were macerated with ten times its weight of the recommended solvent with occasional stirring for $8 \mathrm{~h}$ using mechanical stirrer; then it was set aside overnight $(12 \mathrm{~h})$ at room temperature. The liquid extract was then filtered over thick cotton cloth. This step was repeated three times on the marc. The marc was then washed with double its weight with the recommended solvent. The filtrates were combined with the washing of the marcs, mixed well, and re-filtered using thick cotton cloth filter. The liquid extract was concentrated under vacuum at $5{ }^{\circ} \mathrm{C}$ until a final dry extract was obtained.

\subsubsection{Pilot Supercritical Fluid Carbon Dioxide Extraction Method}

Ten kilograms of finely ground air-dried A. visnaga fruits (with particle size $1 \mathrm{~mm}$ ) were packed in 20 L extraction vessel of $20 \mathrm{~L}$ ASI pilot scale SCFE unit (Applied Separations, Inc. Allentown, PA, USA), which is schematically presented in Figure 2. Extraction was carried out according to previously validated extraction conditions [40] The extraction was started with static time of $2 \mathrm{~h}$, followed by dynamic extraction for another $2 \mathrm{~h}$ with flow rate of supercritical fluid carbon dioxide (containing $5 \%$ methanol as co-solvent) $2 \mathrm{~L} / \mathrm{min}$, supercritical pressure was $200 \mathrm{Bar}$ and supercritical temperature of $45^{\circ} \mathrm{C}$. 


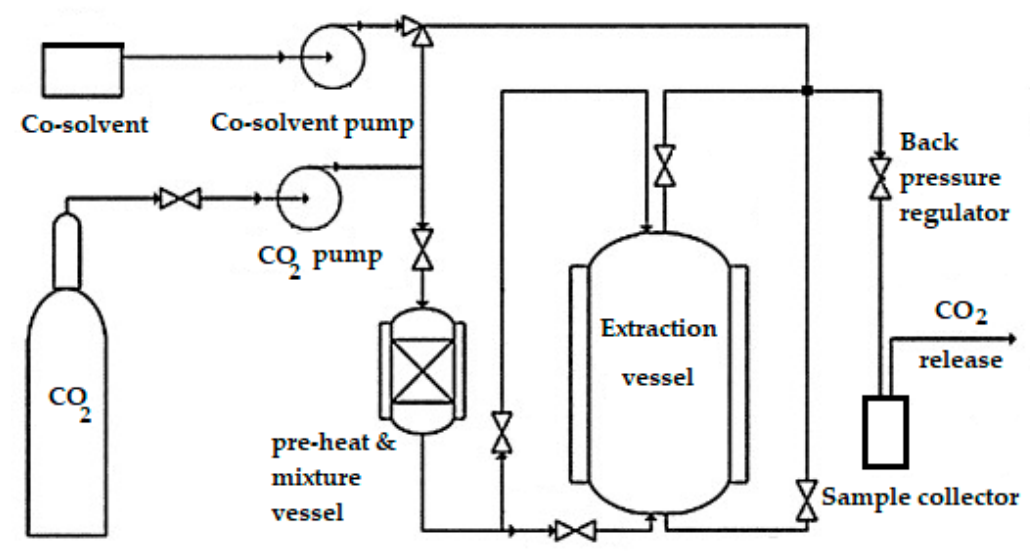

Figure 2. Scheme showing supercritical fluid extraction unit.

\subsection{HPLC Analysis}

Determination of furanochromones in the extracts using standard calibration curves for khellin and visnagin was performed according to a validated method [41]. Analysis was performed using ultra-fast liquid chromatography: Shimadzu, Model Prominence LC20ADXR, equipped with auto sampler, SIL-20ACXR), and PDA detector (Shimadzu Model: SPD-M20A), Kyoto, Japan. Column: ODS3 $(250 \times 4.6 \mathrm{~mm} 5 \mu \mathrm{m}, 100$ A, Phenomenex, Torrance, CA, USA). The injection volume was $20 \mu \mathrm{L}$, detection wavelength was $245 \mathrm{~nm}$ and mobile phase consisted of methanol: water $(50: 50 \mathrm{v} / \mathrm{v})$ at flow rate $1.5 \mathrm{~mL} / \mathrm{min}$. $A$. visnaga extract (15 mg dissolved in methanol) were put in $20 \mathrm{~mL}$ volumetric flask and sonicated (concentration of $75 \mathrm{mg} / \mathrm{dL}$ ). A $0.45 \mu \mathrm{m}$ syringe filter was used for filtration of the solution. Standard khellin and visnagin ( $20 \mathrm{mg}$ dissolved in methanol) were put in 100 $\mathrm{mL}$ volumetric flask, sonicated (concentration of $20 \mathrm{mg} / \mathrm{dL}$ ) and filtered through $0.45 \mu \mathrm{m}$ syringe filter prior to injection with same chromatographic conditions of the sample.

\subsection{Cytotoxic Activity of A. visnaga Extracts, Standard Khellin, Visnagin and Doxorubocin}

Two cell lines (MCF-7 and Hep G2) were used to test the cytotoxic activity of the extracts as well as pure khellin and visnagin. The cells were maintained in the laboratory of National Cancer Institute (Cairo, Egypt). Normal hamster lung fibroblasts (V79 cells) were used as control to assess the safety of samples on normal cells.

Sulforhodamine B stain assay was employed using concentrations 0-200 $\mu \mathrm{g} / \mathrm{mL}$ [42]. Doxorubicin prepared in the previously mentioned concentrations was used as a reference. $\mathrm{IC}_{50}$ in $\mu \mathrm{g} / \mathrm{mL}$, as well as selectivity index (SI) were calculated.

\subsection{Statistical Analysis}

All performed analysis was carried out in triplicate. Values are expressed as mean \pm SEM. Paired-t-test at $p \leq 0.05$ was used to analyze significant difference using GraphPad Prism ${ }^{\circledR}$ v.5.

\section{Conclusions}

Trials for conventional solvent extraction of furanochromones from A. visnaga fruits revealed that the highest yield of furanochromones was obtained using ethanol 95\% $(8.23 \%$ $w / w)$. Using $30 \%$ ethanol was a better choice as a solvent, although it gave a slightly lower yield than acetone $(6.59 \% w / w)$, but acetone is less hazardous, more economic and the extract had much better physical characters. Supercritical fluid extraction of furanochromones was the best method applied as it gave $30.1 \% w / w$ yield with excellent physical characters. Moreover, the SCFE had a stronger cytotoxic activity than the ethanol extract on MCF-7 and Hep G2 cell lines ( $\mathrm{IC}_{50} 17.53$ and $15.39 \mu \mathrm{g} / \mathrm{mL}$, respectively). Therefore, SCFE is a relatively cheap, safe and environment friendly green technique that produced a more selective purified extract free from any residual solvent. This suggests that supercritical fluid extraction may be the method of choice for large scale extraction of furanochromones 
which are incorporated in several pharmaceutical products. However, trials for monitoring SCFE conditions may be carried out in future research to physically separate individual compounds (khellin and visnagin) in the same run. Also, comparison of different sources of $A$. visnaga fruits, as well as studying the effect of different cultivation conditions or plant organ on the yield of furanochromones using SCFE may be implicated in future research.

Author Contributions: Conceptualization, N.K., M.B. and O.S.; Data curation, M.E.-D. and M.A. (Mohamed Amin); Formal analysis, N.K., M.B., M.E.-D. and M.A. (Mohamed Abdelhady); Funding acquisition, M.B.; Investigation, N.K., M.B., M.A. (Mohamed Amin), M.A. (Mohamed Abdelhady) and O.S.; Methodology, M.B., M.E.-D., M.A. (Mohamed Amin) and M.A. (Mohamed Abdelhady); Project administration, N.K. and M.B.; Resources, M.B.; Supervision, M.B. and O.S.; Validation, M.B. and M.A. (Mohamed Amin); Writing — original draft, N.K. and M.A. (Mohamed Amin); Writingreview \& editing, N.K., M.B., M.E.-D., M.A. (Mohamed Abdelhady), M.A. (Mohamed Amin) and O.S. All authors have read and agreed to the published version of the manuscript.

Funding: This work was supported by the Science and Technology Development Fund, Egypt (STDF) through project ID: 5715 entitled "Application of Supercritical Fluid Extraction in Pharmaceutical Industry".

Institutional Review Board Statement: Not applicable.

Informed Consent Statement: Not applicable.

Conflicts of Interest: The authors declare no conflict of interest.

Sample Availability: Samples of the compounds are not available from the authors.

\section{References}

1. Batanouny, K. Wild Medicinal Plants in Egypt: An Inventory to Support Conservation and Sustainable Use; Palm Press: Cairo, Egypt, 1999.

2. Khalil, N.; Bishr, M.; Desouky, S.; Salama, O. Ammi Visnaga L., a Potential Medicinal Plant: A Review. Molecules 2020, $25,301$. [CrossRef]

3. Mucklow, J.C. Martindale: The complete drug reference. Br. J. Clin. Pharmacol. 2000, 49, 613. [CrossRef]

4. Vanachayangkul, P.; Chow, N.; Khan, S.R.; Butterweck, V. Prevention of renal crystal deposition by an extract of Ammi visnaga L. and its constituents khellin and visnagin in hyperoxaluric rats. Urol. Res. 2011, 39, 189-195. [CrossRef]

5. Vanachayangkul, P.; Byer, K.; Khan, S.; Butterweck, V. An aqueous extract of Ammi visnaga fruits and its constituents khellin and visnagin prevent cell damage caused by oxalate in renal epithelial cells. Phytomed. Int. J. Phytother. Phytopharm. 2010, 17, 638-653. [CrossRef] [PubMed]

6. Khan, Z.A.; Assiri, A.M.; Al-Afghani, H.M.; Maghrabi, T.M. Inhibition of oxalate nephrolithiasis with Ammi visnaga (AI-Khillah). Int. Urol. Nephrol. 2001, 33, 605-608. [CrossRef]

7. Gunaydin, K.; Beyazit, N. The chemical investigations on the ripe fruits of Ammi visnaga (Lam.) Lamarck growing in Turkey. Nat. Prod. Res. 2004, 18, 169-175. [CrossRef] [PubMed]

8. Duarte, J.; Vallejo, I.; Perez-Vizcaino, F.; Jimenez, R.; Zarzuelo, A.; Tamargo, J. Effects of visnadine on rat isolated vascular smooth muscles. Planta Med. 1997, 63, 233-236. [CrossRef] [PubMed]

9. Bhagavathula, A.; Mahmoud Al-Khatib, A.; Elnour, A.; Al Kalbani, N.; Shehab, A. Ammi Visnaga in treatment of urolithiasis and hypertriglyceridemia. Pharmacogn. Res. 2015, 7, 397-400.

10. Hashim, S.; Jan, A.; Marwat, K.; Khan, M. Phytochemistry and medicinal properties of Ammi visnaga (Apiacae). Pak. J. Bot. 2014, $46,861-867$.

11. Abu-Hashem, A.; El-Shazly, M. Synthesis, reactions and biological activities of furochromones: A review. Eur. J. Med. Chem 2015, 90, 633-665. [CrossRef]

12. Winderl, B.; Schwaiger, S.; Ganzera, M. Fast and improved separation of major coumarins in Ammi visnaga (L.) Lam. by supercritical fluid chromatography. J. Sep. Sci. 2016, 39, 4042-4048. [CrossRef] [PubMed]

13. Zgorka, G.; Dragan, T.; Glowniak, K.; Basiura, E. Determination of furanochromones and pyranocoumarins in drugs and Ammi visnaga fruits by combined solid-phase extraction-high-performance liquid chromatography and thin-layer chromatographyhigh-performance liquid chromatography. J. Chromatogr. A 1998, 797, 305-309. [CrossRef]

14. Abu-Hashem, A.A.; Youssef, M.M. Synthesis of new visnagen and khellin furochromone pyrimidine derivatives and their anti-inflammatory and analgesic activity. Molecules 2011, 16, 1956-1972. [CrossRef]

15. Ragab, F.A.; El-Sayed, N.A.; Eissa, A.A.; El Kerdawy, A.M. Synthesis and anticonvulsant activity of certain substituted furochromone, benzofuran and flavone derivatives. Chem. Pharm. Bull. 2010, 58, 1148-1156. [CrossRef] [PubMed]

16. Sellami, H.K.; Napolitano, A.; Masullo, M.; Smiti, S.; Piacente, S.; Pizza, C. Influence of growing conditions on metabolite profile of Ammi visnaga umbels with special reference to bioactive furanochromones and pyranocoumarins. Phytochemistry 2013, 95, 197-206. [CrossRef] [PubMed] 
17. Harvengt, C.; Desager, J. HDL-cholesterol increase in normolipaemic subjects on khellin: A pilot study. Int. J. Clin. Pharmacol. Res. 1983, 3, 363-366. [PubMed]

18. Duarte, J.; Torres, A.I.; Zarzuelo, A. Cardiovascular effects of visnagin on rats. Planta Med. 2000, 66. [CrossRef]

19. Voros, V.; Drioli, E.; Fonte, C.; Szekely, G. Process Intensification via Continuous and Simultaneous Isolation of Antioxidants: An Upcycling Approach for Olive Leaf Waste. ACS Sustain. Chem. Eng. 2019, 7, 18444-18452. [CrossRef]

20. Didaskalou, C.; Buyuktiryaki, S.; Kecili, R.; Fonte, C.P.; Szekely, G. Valorisation of agricultural waste with an adsorption/nanofiltration hybrid process: From materials to sustainable process design. Green Chem. 2017, 19, 3116-3125. [CrossRef]

21. Wang, J.; Jing, W.; Tian, H.; Liu, M.; Yan, H.; Bi, W.; Chen, D.D.Y. Investigation of Deep Eutectic Solvent-Based Microwave-Assisted Extraction and Efficient Recovery of Natural Products. ACS Sustain. Chem. Eng. 2020, 8, 12080-12088. [CrossRef]

22. Cao, D.; Liu, Q.; Jing, W.; Tian, H.; Yan, H.; Bi, W.; Jiang, Y.; Chen, D.D.Y. Insight into the Deep Eutectic Solvent Extraction Mechanism of Flavonoids from Natural Plant. ACS Sustain. Chem. Eng. 2020, 8, 19169-19177. [CrossRef]

23. Nahar, L.; Sarker, S.D. Supercritical fluid extraction in natural products analyses. Methods Mol. Biol. 2012, 864, 43-74. [PubMed]

24. Ashraf-Khorassani, M.; Combs, M.; Taylor, L. Supercritical fluid extraction of metal ions and metal chelates from different environments. J. Chromatogr. A 1997, 774, 37-49. [CrossRef]

25. Zougagh, M.; Valcárcel, M.; Ríos, A. Supercritical fluid extraction: A critical review of its analytical usefulness. Trend. Anal. Chem. 2004, 23, 399-405. [CrossRef]

26. Pourmortazavi, S.; Hajimirsadeghi, S. Supercritical fluid extraction in plant essential and volatile oil analysis. J. Chromatogr. A 2007, 1163, 2-24. [CrossRef]

27. Careri, M.; Furlattini, L.; Mangia, A.; Musc, M.; Anklam, E.; Theobald, A.; von Holst, C. Supercritical fluid extraction for liquid chromatographic determination of carotenoids in Spirulina pacifica algae: A chemometric approach. J. Chromatogr. A 2001, 912, 61-71. [CrossRef]

28. Brachet, A.; Mateus, L.; Cherkaoui, S.; Christen, P.; Gauvrit, J.-Y.; Lantéri, P.; Veuthey, J.-L. Application of central composite designs in the supercritical fluid extraction of tropane alkaloids in plant extracts. Analusis 1999, 27, 772-778. [CrossRef]

29. Egydio, J.; Moraes, Â.; Rosa, P. Supercritical fluid extraction of lycopene from tomato juice and characterization of its antioxidation activity. J Supercrit. Fluids 2010, 54, 159-164. [CrossRef]

30. Ambrosino, P.; Fresa, R.; Fogliano, V.; Monti, S.M.; Ritieni, A. Extraction of azadirachtin A from neem seed kernels by supercritical fluid and its evaluation by HPLC and LC/MS. J. Agric. Food Chem. 1999, 47, 5252-5256. [CrossRef]

31. Campos, L.; Michielin, E.; Danielski, L.; Ferreira, S. Experimental data and modeling the supercritical fluid extraction of marigold (Calendula officinalis) oleoresin. J. Supercrit. Fluids 2005, 34, 163-170. [CrossRef]

32. Han, Z.; Wang, X.; Xu, M.; Wang, Y.; Yang, L.; Han, M. Optimization of Supercritical Fluid Extraction and Rapid Resolution LC-MS/ESI Identification of Chromones from Saposhnikoviae radix through Orthogonal Array Design. Chin. Herb. Med. 2016, 8, 314-322. [CrossRef]

33. Khaw, K.Y.; Parat, M.O.; Shaw, P.N.; Falconer, J.R. Solvent supercritical fluid technologies to extract bioactive compounds from natural sources: A Review. Molecules 2017, 22, 1186. [CrossRef]

34. Herrero, M.; Cifuentes, A.; Ibañez, E. Sub- and supercritical fluid extraction of functional ingredients from different natural sources: Plants, food-by-products, algae and microalgae: A review. Food Chem. 2006, 98, 136-148. [CrossRef]

35. Da Silva, R.P.F.F.; Rocha-Santos, T.A.P.; Duarte, A.C. Supercritical fluid extraction of bioactive compounds. TrAC Trends Anal. Chem. 2016, 76, 40-51. [CrossRef]

36. Vlietinck, A.J. Screening Methods for Detection and Evaluation of Biological Activities of Plant Preparations. In Bioassay Methods in Natural Product Research and Drug Development; Bohlin, L., Bruhn, J.G., Eds.; Springer: Dordrecht, The Netherlands, 1999; pp. 37-52.

37. Cordero, C.P.; Gómez-González, S.; León-Acosta, C.J.; Morantes-Medina, S.J.; Aristizabal, F.A. Cytotoxic activity of five compounds isolated from Colombian plants. Fitoterapia 2004, 75, 225-227. [CrossRef]

38. Ashour, A.; El Sharkawy, S.; Amer, M.; Abdelbar, F.; Kondo, R. Melanin Biosynthesis Inhibitory Activity of Compounds Isolated from Unused Parts of Ammi visinaga. J. Cosmet. Dermatol. Sci. Appl. 2013, 3, 40-43.

39. Beltagy, A.M.; Beltagy, D.M. Chemical composition of Ammi visnaga L. and new cytotoxic activity of its constituents Khellin and Visnagin. J. Pharm. Sci. Res. 2015, 7, 285-291.

40. Bishr, M.; El-Degwy, M.; Abdel Hady, M.; Amin, M.; Salama, O. Supercritical fluid extraction of $\gamma$-Pyrones from Ammi visnaga L. fruits. Future J. Pharm. Sci. 2018, 4, 57-62. [CrossRef]

41. Bishr, M.; El Degwy, M.; AbdelHady, M.; Amin, M.; Salama, O. HPLC simultaneous determination of khellin and visnagin in Ammi visnaga L. fruits. IOSR J. Pharm. Biol. Sci. 2016, 11, 110-115.

42. Skehan, P.; Storeng, R.; Scudiero, D.; Monks, A.; McMahon, J.; Vistica, D.; Warren, J.T.; Bokesch, H.; Kenney, S.; Boyd, M.R. New colorimetric cytotoxicity assay for anticancer-drug screening. J. Natl. Cancer Inst. 1990, 82, 1107-1112. [CrossRef] 